\title{
Mayoral candidate assails activist doctors
}

Published at www.cmaj.ca on Apr. 30

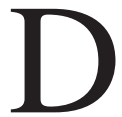
octors should not be advocating for the poor, says a Toronto, Ontario, mayoral candidate who filed a complaint that has a family doctor facing potential loss or suspension of his licence to practice.

"A doctor is there to be a doctor, not to advocate for the poor, or to be the official opposition in government through taxpayer's money," says Toronto City Councillor Robert Ford, a conservative candidate for the city's top job in the October 2010 municipal elections. "That's frightening, when I think about it. You can't have people in the medical field doing that."

Ford asked the College of Physicians and Surgeons of Ontario to investigate Dr. Roland Wong last year for improperly filling out special diet forms that until recently allowed welfare recipients to obtain financial assistance to purchase food needed to allay the effects of such medical conditions as food allergies, celiac disease and diabetes (CMAJ 2010. DOI:10.1503/cmaj.109-3232).

Ford says as many as "three or four" people told him that Wong had filled out forms to allow people on social assistance to access extra money to help them deal with food allergies, even though they were not allergic.

Wong, who specializes in occupation and community medicine, says he has completed as many as 15000 special diet forms for social assistance recipients in one year.

But Wong insists he has never harmed anyone or acted improperly or illegally in doing so. In addition to signing forms for his own patients, he also signed them for people attending mass clinics arranged by poverty advocates around the province.

Wong now faces a disciplinary hearing at the college, which is investigating whether he failed to meet the standards of the profession or engaged in conduct that "would reasonably be

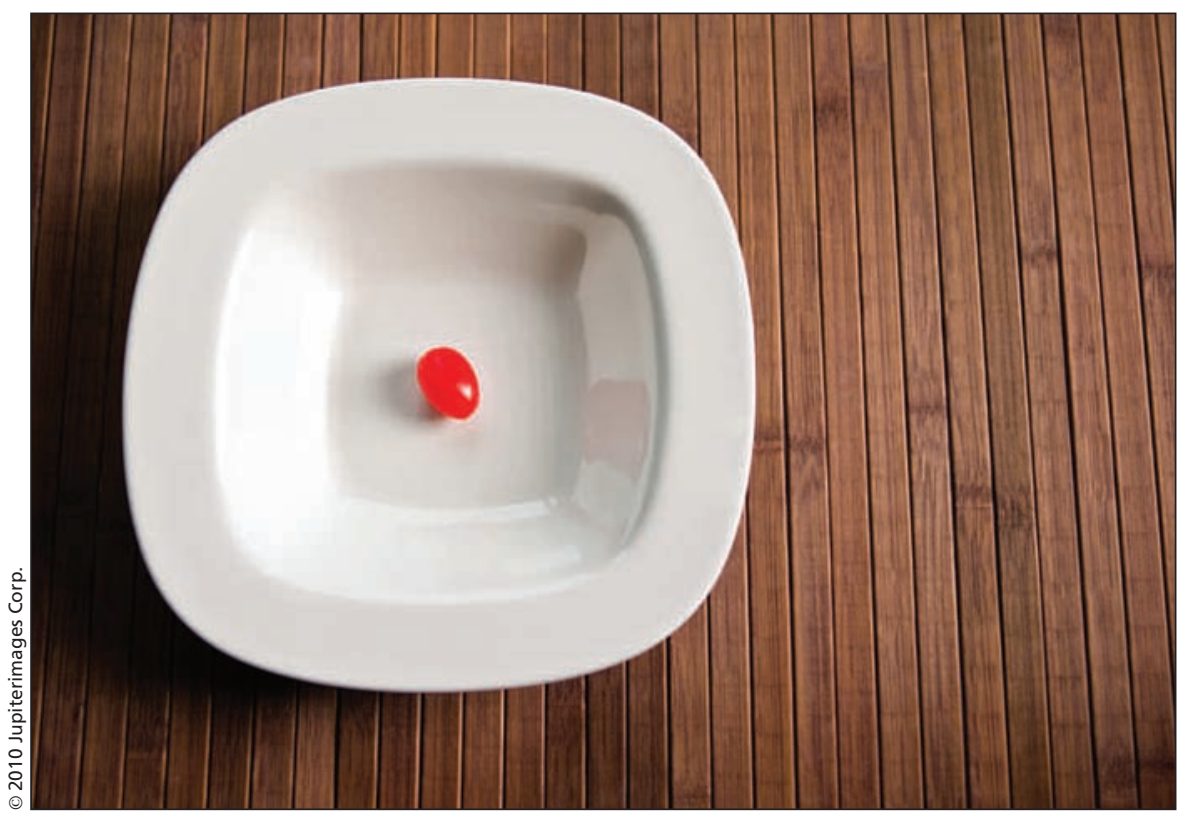

"Large numbers of people die needlessly because of misguided provincial policies," says Toronto, Ontario, family physician Dr. Roland Wong.

regarded by members as disgraceful, dishonourable or unprofessional,' according to the notice of hearing issued by the college.

"The Inquiries, Complaints and Reports committee of the College of Physicians and Surgeons of Ontario has also referred to the Discipline Committee the allegation that Dr. Wong is incompetent as defined by subsection 52(1) of the Health Professions Procedural Code, which is Schedule 2 to the Regulated Health Professions Act, 1991, ("the Code")" the notice says.

The hearing, which has not yet been scheduled, could result in the loss or suspension of Wong's licence, or in a fine.

Wong says the complaint against him is politically motivated and the province is putting pressure on the college to act.

"It is a form of harassment," he says. "I don't think it's come up too often when a complaint was not made by a patient, but by a politician."

In its fiscal year 2010/11 budget, Ontario cancelled the diet allowance program, which provided additional benefits of up to $\$ 250$ per month for 136250 people on social assistance to buy healthy food because of their medical conditions. The province cited ballooning costs as the rationale for the cut, as the program's price tag had swelled to $\$ 220$ million in fiscal $2009 / 2010$, up from $\$ 6$ million in 2001/02.

Community and Social Services Minister Madeleine Meilleur also cited an auditor general's report saying the program was being abused. Meilleur noted that doctors and other health care professionals were signing the forms without properly examining clients.

Ford claims he has "no axes to grind" and says people often come to him with complaints, including healthrelated ones. He says he has never before gone to the college about a doctor and does not know if Wong improperly filled out forms. "Being the son of a [former] MPP [member of the provincial parliament] ... and being close friends of the [federal] Finance Minister, Jim Flaherty — I 
think people know that I know how politics works. I know how to get things done and which departments to complain to," he says.

Other physicians have spoken out against the cancellation of the diet allowances, arguing that it will cost the province more in the long-term because of the health consequences. They also say Wong cannot be held accountable for $\$ 200$ million spent under the program.

"He is a very strong advocate for this," says Dr. Gary Bloch, a family physician at St. Michael's Hospital in Toronto and a member of Health
Providers Against Poverty. "This is clearly an attempt to muzzle him. Luckily, he's not someone who is easily muzzled. He has not drawn back from talking about this."

That was evident in an Apr. 6 address that Wong gave at an event organized by the Ontario Public Interest Research Group to protest cuts to the program. "Income level is the best predictor of health," he told the protesters. "For every rich person with diabetes, about 2.6 people will have diabetes. Large numbers of people die needlessly because of misguided provincial policies. More will die as
[Ontario Premier Dalton] McGuinty's misguided policies continue to suffocate the poor."

Wong adds that caring for the less fortunate is a Canadian value. "My background is that I've seen enough to know the amount of money they [welfare recipients] were getting, around $\$ 500$ [a month], isn't going to carry them too far. I suppose I'm different than other people - I'm willing to take some risks. I'm willing to help them," he says. - Laura Eggertson, Ottawa, Ont.

DOI:10.1503/cmaj.109-3248 